SMU Law Review Forum

\title{
The Texas Legislature Has Significantly Broadened the Statute Governing Recovery of Attorney's Fees in Breach of Contract Cases
}

\author{
Gregory Scott Crespi \\ Southern Methodist University, Dedman School of Law \\ West Menefee Bakke \\ Southern Methodist University, Dedman School of Law
}

\section{Recommended Citation}

Gregory Scott Crespi \& West Menefee Bakke, The Texas Legislature Has Significantly Broadened the Statute Governing Recovery of Attorney's Fees in Breach of Contract Cases, 74 SMU L. REV. F. 130 (2021)

This Article is brought to you for free and open access by the Law Journals at SMU Scholar. It has been accepted for inclusion in SMU Law Review Forum by an authorized administrator of SMU Scholar. For more information, please visit http://digitalrepository.smu.edu. 


\title{
SMU Law Review Forum
}

\begin{tabular}{||lc|}
\hline \hline Volume 74 & August 2021 \\
\hline
\end{tabular}

\section{THE TEXAS LEGISLATURE HAS SIGNIFICANTLY BROADENED THE STATUTE GOVERNING RECOVERY OF ATTORNEY'S FEES IN BREACH OF CONTRACT CASES}

\author{
West Menefee Bakke*
}

Gregory Scott Crespi ${ }^{* *}$

\begin{abstract}
Texas recently enacted amendments that significantly expand the scope of section 38.001 of the Texas Civil Practice $\mathcal{E}$ Remedies Code, a statute that awards attorney's fees to successful claimants in breach of contract cases. Under the new amendments, which take effect September 1, 2021, the prevailing party may recover reasonable attorney's fees from most forms of business organizations, including partnerships and limited liability companies-not just from individuals and corporations, as the statute previously provided. And although there has been some confusion on this point, the amended statute continues to protect governments and governmental agencies from attorney's fees liability. Additionally, the amendments expressly preclude recovery of fees against certain quasigovernmental organizations providing public services and religious or charitable organizations.
\end{abstract}

\section{INTRODUCTION TO SECTION 38.001}

Section 38.001 of the Texas Civil Practice \& Remedies Code is a broad attorney's fees statute that allows a person to recover reasonable attorney's fees from an "individual or corporation" if "the claim is for ... an oral or written

* J.D., May 2021, Dedman School of Law, Southern Methodist University.

** Homer R. Mitchell Professor of Law, Dedman School of Law, Southern Methodist University. 
contract." ${ }^{1}$ As one of us has discussed in a prior 2012 article, ${ }^{2}$ this rather terse statute raises a number of difficult interpretive issues. ${ }^{3}$ The most difficult and oftlitigated issue under this statute is whether organizations such as governments, partnerships, limited partnerships, and limited liability companies qualify as "corporations" that may be held liable for attorney's fees. ${ }^{4}$

Section 38.001's predecessor, article 2226 of the Texas Revised Civil Statutes, used the phrase "person or corporation" rather than the phrase "individual or corporation." In 1985, however, article 2226 was replaced by section $38.001^{6}$ as part of the Texas Legislative Council's efforts "to clarify and simplify the statutes and to make the statutes more accessible, understandable, and usable." ${ }^{7}$ The newly substituted "individual or corporation" language appearing in section 38.001 was apparently intended to merely preserve the existing state of the law in the face of the Code Construction Act's definition of "person," broadly defined to include a "government or governmental subdivision or agency"

1. TeX. Civ. Prac. \& ReM. Code ANN. § 38.001(8). The full text of section 38.001 reads as follows:

Sec. 38.001. RECOVERY OF ATTORNEY'S FEES. A person may recover reasonable attorney's fees from an individual or corporation, in addition to the amount of a valid claim and costs, if the claim is for:

(1) rendered services;

(2) performed labor;

(3) furnished material;

(4) freight or express overcharges;

(5) lost or damaged freight or express;

(6) killed or injured stock;

(7) a sworn account; or

(8) an oral or written contract.

Id.

2. Gregory Scott Crespi, Who Is Liable for Attorney's Fees Under Texas Civil Practice $\mathcal{E}$ Remedies Code Section 38.001 in Breach of Contract Litigation?, 65 SMU L. REV. 71, 71 (2012).

3. Such interpretive issues outside the scope of the present discussion include the significance, if any, of the statute's construction "for ... a on oral or written contract," instead of "for . . . breach of an oral or written contract"; the availability of fee recovery where no damages are awarded, as in an action for declaratory judgment; the entitlement of a defendant to recover attorney's fees from a plaintiff whose claim is successfully defended against; and the applicability of the statute in actions where foreign law supplies the substantive rule of decision, such as where the contract contains an enforceable choice-of-law clause. See id. at $71 \mathrm{n} .2$ (citation omitted).

4. See, e.g., State v. Bodisch, 775 S.W.2d 73, 74-75 (Tex. App.-Austin 1989, writ denied) (state and state agency); Base-Seal, Inc. v. Jefferson Cnty., 901 S.W.2d 783, 785-88 (Tex. App.-Beaumont 1995, writ denied) (county); Ganz v. Lyons P'ship, 173 F.R.D. 173, 175-77 (N.D. Tex. 1997) (limited partnership); Fleming \& Assocs., L.L.P. v. Barton, 425 S.W.3d 560, 574-76 (Tex. App.-Houston [14th Dist.] 2014, pet. denied) (limited liability partnership); Alta Mesa Holdings, L.P. v. Ives, 488 S.W.3d 438, 452-55 (Tex. App.-Houston [14th Dist.] 2016, pet. denied) (limited liability company).

5. Act of May 11, 1971, 62d Leg., R.S., ch. 225, § 1, art. 2226, 1971 Tex. Gen. Laws 1073, 1073, repealed by Act of May 17, 1985, 69th Leg., R.S., ch. 959 § 9(1), 1985 Tex. Gen. Laws 3242, 3322; see Crespi, supra note 2, at 73-74.

6. Act of May 17, 1985, 69th Leg., R.S., ch. 959 § 1, sec. 38.001, 1985 Tex. Gen. Laws 3242, 3278-79 (codified at TEX. CIV. PRAC. \& REM. CODE ANN. § 38.001).

7. TEX. GOV'T CODE ANN. § 323.007(a).

8. Code Construction Act, 60th Leg., R.S., ch. 455, § 1, sec. 1.04(2), 1967 Tex. Gen. Laws 
had previously been held to be outside the scope of attorney's fees liability under article $2226 .{ }^{9}$

While section 38.001 does not appear to have been intended to exempt nongovernmental organizations such as partnerships, limited partnerships, or limited liability companies from potential liability, recent court rulings have nevertheless interpreted the "individual or corporation" statutory phrase literally and narrowly to not cover those kinds of non-corporate entities. ${ }^{10}$

\section{2021 AMENDMENTS TO SECTION 38.001}

Given the lack of a convincing policy rationale for treating partnerships and limited liability companies more favorably than corporations with regard to responsibility for attorney's fees, there have unsurprisingly been legislative efforts made in recent years to amend section 38.001 to cover lawsuits against these noncorporate private entities. ${ }^{11}$ Those efforts finally proved successful in 2021, when Governor Abbott signed into law House Bill (H.B.) 1578 on June $15 .^{12}$ That legislation will go into effect on September 1, 2021 for lawsuits filed on or after that date (but not for lawsuits pending as of that date),$^{13}$ and it broadens the scope of section 38.001 to cover all "organization[s]" (a term which, by statute, does not

1036, 1036 (repealed 1985). The Act has since been included in the Texas Government Code as part of the statutory revision program. Act of May 17, 1985, 69th Reg., R.S., ch. 479, § 1, 1985 Tex. Gen. Laws 1652, 1670-73 (codified at TEX. GOV'T CODE ch. 311).

9. In the words of section 38.001's drafters, "[t]he revised law does not use 'person' in the reference to an opposing party because the Code Construction Act definition of 'person' is broader than the source law meaning of the term.” TEX. LEGIS. COUNCIL, CIVIL PRACTICE AND REMEDIES CODE: A NONSUbSTANTIVE REVISION OF THE STATUTES RELATING TO CIVIL PROCEDURE AND CIVIL REMEDIES AND LIABILITIES 178 (1984). The "source law"-i.e., article 2226-did not impose potential liability for attorney's fees upon governmental entities, according to most courts. See Crespi, supra note 2, at 74 (citing City of Austin v. N. Austin State Bank, 631 S.W.2d 564, 568 (Tex. App.Austin 1982, no writ); and then citing Comm'rs Court v. Rodgers, 691 S.W.2d 753, 757 (Tex. App.Tyler 1982, no writ)).

10. See, e.g., Fleming \& Assocs., L.L.P. v. Barton, 425 S.W.3d 560, 576 (Tex. App.-Houston [14th Dist.] 2014, pet. denied) (holding section 38.001 does not permit recovery against a partnership); Choice! Power, L.P. v. Feeley, 501 S.W.3d 199, 214 (Tex. App.-Houston [1st Dist.] 2016, no pet.) (holding that section 38.001 does not permit recovery against a limited partnership); First Cash, Ltd. v. JQ-Parkdale, LLC, 538 S.W.3d 189, 200 (Tex. App.-Corpus Christi-Edinburg 2018, no pet.) (holding that section 38.001 does not permit recovery against a limited liability company); see also Taylors Int'l Servs., Inc. v. Cuero Oilfield Hous., LLC, No. A-16-CA-512-SS, 2016 WL 8674349, at *1 (W.D. Tex. Oct. 31, 2016) ("There is no logic to the law eliminating attorney's fees that would be owed by individuals and corporations, but that is exactly what Texas has done.").

11. Several bills introduced in past years, for example, would have amended section 38.001 to authorize recovery of reasonable attorney's fees "from an individual, corporation, or other legal entity.” E.g., Tex. H.B. 274, 82d Leg., R.S. § 2, sec. 38.001 (2011) (as introduced Mar. 10, 2011); Tex. H.B. 230, 84th Leg., R.S. § 1, sec. 38.001(a) (2015) (as introduced Nov. 11, 2014); Tex. H.B. 744, 85th Leg., R.S. § 1, sec. 38.001(a) (2017) (as introduced Dec. 27, 2016); see also, e.g., Tex. H.B. 370, 86th Leg., R.S. § 1, secs. 38.001(a)-(b) (2019) (as introduced Nov. 15, 2018) (authorizing recovery of fees from "an individual or a corporation or other organization," with the last term having the meaning assigned by section 1.002(62) of the Texas Business Organizations Code).

12. Act of May 28, 2021, 87th Leg., R.S., H.B. 1578 (to be codified as an amendment to TeX. CIV. PRAC. \& REM. CODE $§ 38.001$.

13. Id. $\S \S 2-3$. 
encompass governments or governmental agencies) ${ }^{14}$ except for exempting from potential liability those organizations which are either "a quasi-governmental entity authorized to perform a function by state law, a religious organization, a charitable organization, or a charitable trust." ${ }^{15}$

So, the amended statute, when it goes into effect this fall, will now extend to impose potential attorney's fees liability on partnerships, limited partnerships, limited liability partnerships and limited liability companies, as well as on individuals and corporations, although it will still exclude governments and governmental agencies from potential liability and will now also expressly exclude a few other quasi-governmental or private religious or charitable organizations from potential liability. Importantly, the new statute does not broaden the scope of the prior statute to permit successful defendants in breach of contract actions to recover their attorney's fees; it is not a full two-way fee-shifting statute. ${ }^{16}$

14. For the meaning of "organization," H.B. 1578 expressly calls for the definition contained in the Texas Business Organizations Code. See Tex. H.B. 1578, 87th Leg., R.S. § 1, sec. 38.001(a) (2021). That definition, in turn, does not encompass governments:

"Organization" means a corporation, limited or general partnership, limited liability company, business trust, real estate investment trust, joint venture, joint stock company, cooperative, association, bank, insurance company, credit union, savings and loan association, or other organization, regardless of whether the organization is for-profit, nonprofit, domestic, or foreign.

TEX. BUS. ORGS. CODE ANN. § 1.002(62). Although the Code's definition of "organization" could perhaps more clearly exclude governments from its "or other organization" catchall phrase, the later "regardless of ..." list that does not mention them suggests this was the legislative intent. See id. This reading is corroborated by the fact that when the Code intends to include governments within a given definition, it does so expressly; take, for example, the Code's definition of "person":

"Person" means an individual or a corporation, partnership, limited liability company, business trust, trust, association, or other organization, estate, government or governmental subdivision or agency, or other legal entity, or a series of a domestic limited liability company or foreign entity.

Id. $\S 1.002$ (69-b) (emphasis added).

15. Tex. H.B. 1578, 87 th Leg., R.S. § 1, sec. 38.001(b) (2021). The full text of section 38.001 as it will appear once H.B. 1578's amendments go into effect on September 1, 2021, is set forth below:

Sec. 38.001. RECOVERY OF ATTORNEY'S FEES. (a) In this section, "organization” has the meaning assigned by Section 1.002, Business Organizations Code.

(b) A person may recover reasonable attorney's fees from an individual or organization other than a quasi-governmental entity authorized to perform a function by state law, a religious organization, a charitable organization, or a charitable trust, in addition to the amount of a valid claim and costs, if the claim is for:

(1) rendered services;

(2) performed labor;

(3) furnished material;

(4) freight or express overcharges;

(5) lost or damaged freight or express;

(6) killed or injured stock;

(7) a sworn account; or

(8) an oral or written contract.

Id. $\S 1$.

16. See, e.g., Am. Airlines, Inc. v. Swest, Inc., 707 S.W.2d 545, 547 (Tex. 1986) (holding 
The convoluted legislative process by which H.B. 1578 was adopted has unfortunately led to some confusion among commentators as to the scope of the amendments to section 38.001. Let us briefly explain. Senate Bill (S.B.) 808 was introduced in the Texas Senate in March 2021, ${ }^{17}$ and that bill proposed amending section 38.001 by substituting the phrase "another person" for the phrase "individual or corporation." ${ }^{18}$ After being passed by the Senate in that form on April 19, 2021, ${ }^{19}$ the bill was then sent to the Texas House, which then on May 18, 2021 substituted the more limiting phrase "an individual or organization" for the Senate's "another person" phrase before passing the legislation. ${ }^{20}$ The House and Senate therefore passed different versions of S.B. 808. At approximately the same time (April 20, 2021), the House passed H.B. 1578, ${ }^{21}$ which would (like the House's version of S.B. 808) amend section 38.001 to cover "an individual or organization." ${ }^{22}$ The House then sent that legislation on to the Senate for its consideration. ${ }^{23}$

After the House passage of H.B. 1578, and with the House and Senate's prior passages of different versions of S.B. 808, the Senate was then presented with several choices as to how to proceed. These options included: (1) concurring in the House's changes to S.B. 808, enrolling and delivering it to the Governor for his signature; (2) refusing to concur in the House's changes to S.B. 808, appointing a House-Senate conference committee to resolve the differences between the House and Senate versions; (3) passing H.B. 1578 without amendment, enrolling and delivering it to the Governor for his signature; or (4) amending H.B. 1578 in some manner, prompting the House (as the originating chamber) to either concur in the amendments or appoint a conference committee

defendant could not recover attorney's fees under predecessor to section 38.001 when defendant did not present a contract claim); Polansky v. Berenji, 393 S.W.3d 362, 368 (Tex. App.-Austin 2012, no pet.) (holding defendants could not recover attorney's fees where it "answered the [plaintiff]s' breachof-contract claim with a general denial and did not present any claim of their own"); Brockie v. Webb, 244 S.W.3d 905, 910 (Tex. App.-Dallas 2008, pet. denied) ("Section 38.001 does not provide for attorney's fees in the pure defense of a claim."); Energen Res. MAQ, Inc. v. Dalbosco, 23 S.W.3d 551, 558 (Tex. App.-Houston [1st Dist.] 2000, pet. denied) (holding defendant that did not present its own claim under chapter 38 could not recover attorney's fees).

17. S.J. OF TEX., 87th Leg., R.S. 238 (2021).

18. Tex. S.B. 808, 87th Leg., R.S. $\S 1$ (2021) (as introduced Feb. 25, 2021). In addition to substituting "another person" for the phrase "individual or corporation," the text of S.B. 808 as introduced would have added a new subsection to section 38.001 allowing a defendant to recover attorney's fees in a breach of contract action. See id. The Senate Committee on State Affairs, however, killed this subsection by substituting a new bill for the original bill. See Tex. S.B. 808, 87th Leg., R.S. $\S 1$ (2021) (as reported by S. Comm. on State Affs., Mar. 24, 2021); see generally TEX. LEGIS. COUNCIL, THE Legislative PROCESS IN TEXAS, at 2-3 (2021), https://tlc.texas.gov/docs/legref/legislativeprocess.pdf [https://perma.cc/3THT-6Q8Y] (explaining committee's powers upon referral of bill). For a full history of S.B. 808's text, see $87(R)$ Text for SB 808, TEX. TEG. ONLINE, https://capitol.texas.gov/BillLookup/Text.aspx?LegSess=87R\&Bill=SB808, [https://perma.cc/BM3Q-TK9L].

19. S.J. OF TEX., 87th Leg., R.S. 845 (2021).

20. H.J. OF TEX., 87th Leg., R.S. 3347, 3401-02 (2021).

21. Id. at $1285-86$

22. Tex. H.B. 1578, 87th Leg., R.S. § 1 (2021) (as engrossed by House, Apr. 20, 2021).

23. H.J. OF TEX., 87th Leg., R.S. 1399 (2021). 
to resolve the differences between the House and Senate versions. ${ }^{24}$ On May 24, 2021, the Senate chose the last option, adopting an amendment to H.B. 1578 that carved out quasi-governmental, religious, or charitable organizations from attorney's fees liability. ${ }^{25}$ On May 28, 2021, the House concurred in the Senate's amendments. ${ }^{26}$ The bill was then sent to the Governor, ${ }^{27}$ who signed H.B. 1578 into law on June $15,2021 .^{28}$

We provide this clarifying legislative detail because a recent Texas Lawbook article apparently misunderstood this rather confusing legislative process and incorrectly stated that S.B. 808 and its very broad "another person" criterion reflected in the Senate version will go into effect on September 1, 2021. ${ }^{29}$ But it is H.B. 1578 that will go into effect, not either version of S.B. 808 , and the new language provided by H.B. 1578 not only contains an "organization" limitationwhich under section 1.002(62) of the Texas Business Organizations Code will continue to exclude governments and governmental agencies from potential liability-but also exempts a limited group of private entities.

\section{CONCLUSION}

H.B. 1578 thus considerably broadens the scope of section 38.001, effective September 1, 2021, to now include potential attorney's fees liability for various forms of partnerships and for limited liability companies-a very significant (and, in our opinion, long-overdue) change. But, contrary to the statements expressed in the Texas Lawbook article, this amendment does not go so far as to extend potential attorney's fees to governmental agencies, or to private religious or charitable organizations.

24. See generally TEX. LEGIS. COUNCIL, supra note 18, at 5-7 (explaining procedures with respect to final stages of a bill).

25. S.J. OF TEX., 87th Leg., R.S. 1822-23 (2021).

26. H.J. OF TEX., 87th Leg., R.S. 4488-89 (2021).

27. Id. at 5517 .

28. Id. at 5519 .

29. Nick Brown \& Kevin Jacobs, Texas Legislature Clarifies Limits on Recovering Attorneys' Fees in Breach of Contract Cases, TEX. LAWBOOK (June 29, 2021), https://texaslawbook.net/texas-legislatureclarifies-limits-on-recovering-attorneys-fees-in-breach-of-contract-cases/ [https://perma.cc/4NC825TD]. The article claimed:

On May 19, the Texas Senate and Texas House approved S.B. 808, an amendment that eliminated the restriction that fees may be recovered from only an individual or corporation by rewriting that portion of the statute. Beginning Sept. 1, the successful party in a breach of contract action will be able to recover reasonable attorneys' fees from "another person," a term defined in the Code Construction Act to include a "corporation, organization, government or governmental subdivision or agency, business trust, estate, trust, partnership, association, and any other legal entity. 